\title{
Pengaruh Literasi Keuangan Terhadap Keputusan Keuangan Dan Perilaku Keuangan Sebagai Variabel Intervening Mahasiswa Fakultas Ekonomi Dan Bisnis Universitas Palangka Raya
}

\author{
Hengky Kurniawan ${ }^{1)}$ \\ Fakultas Ekonomi dan Bisnis \\ Universitas Palangka Raya, Indonesia \\ Solikah Nurwati $^{2)}$ \\ Fakultas Ekonomi dan Bisnis \\ Universitas Palangka Raya, Indonesia \\ Rita Sarlawa \\ Fakultas Ekonomi dan Bisnis \\ Universitas Palangka Raya, Indonesia
}

Email: khengkykurniawan97@gmail.com

\begin{abstract}
Abstrak
Tujuan - Penelitian ini bertujuan untuk memberikan penjelasan secara empiris tentang pengaruh literasi keuangan terhadap keputusan keuangan dan perilaku keuangan sebagai variabel intervening.

Desain/Metodelogi/Pendekatan - Metode penelitian menggunakan deskriptif-kuantitatif. Sumber data diperoleh dari penyebaran kusioner terhadap 96 mahasiswa di Fakultas Ekonomi dan Bisnis Universitas Palangka Raya. Sampel diambil dari keseluruhan mahasiswa Fakultas Ekonomi dan Bisnis Universitas Palangka Raya yang berjumlah 2.598 yang diambil secara purposive sampling. Data yang terkumpul dianalisis dengan menggunakan pendekatan Structural Equation Modelling (SEM). Software yang digunakan adalah SmartPLS 3.0.

Temuan Penelitian - Hasil penelitian menunjukkan bahwa literasi keuangan berpengaruh positif signifikan terhadap keputusan keuangan, literasi keuangan berpengaruh positif signifikan terhadap perilaku keuangan, perilaku keuangan berpengaruh positif signifikan terhadap keputusan keuangan, perilaku keuangan mampu memediasi pengaruh antara literasi keuangan terhadap keputusan keuangan.

Orsinalitas/nilai - Mengembangkan konsep teori dari perilaku keuangan sebagai mediasi antar pengaruh literasi keuangan dengan keputusan keuangan.

Kata kunci: Literasi Keuangan, Keputusan Keuangan, Perilaku Keuangan.

\section{The Effect Of Financial Literacy On Financial Decisions And Financial Behavior As An Intervening Variable In Students Of The Faculty Of Economics And Business At Palangka Raya University}

\section{Abstract}

Purpose - This study aims to provide an empirical explanation of the influence of financial literacy on financial decisions and financial behavior as an intervening variable.

Design /Methodology / Approach - The research method used is descriptive-quantitative. The source of the data was obtained from the distribution of questionnaires to 96 students in the Faculty of Economics and Business at Palangka Raya University. Samples were taken from all students of the Faculty of Economics and Business, University of Palangka Raya, totaling 2,598 taken proportionally using purposive sampling techniques. The data collected was analyzed using the Structural Equation Modeling (SEM) approach. The software used is SmartPLS 3.0.

Research Findings - The results show that financial literacy has a significant positive effect on financial decisions, financial literacy has a significant positive effect on financial behavior, financial behavior has a significant positive effect on financial decisions, financial behavior is able to mediate the effect of financial literacy on financial decisions

.Keywords: Financial Literacy, Financial Decisions, Financial Behavior.

Jurnal Manajemen Sains dan Organisasi Vol 1, No 1, 2020 pp. $50-63$ FEB UPR
Hengky Kurniawan, Solikah Nurwati, and Rita Sarlawa. Published in the Jurnal Manajemen sains dan Organsasi. Published by FEB UPR Publishing Limited. This article is published under the Creative Commons Attribution (CC BY 4.0) licence. Anyone may reproduce, distribute, translate and create derivative works of this article (for both commercial and non-commercial purposes), subject to full attribution to the original publication and authors. 


\section{Pendahuluan}

Masalah keuangan sering kali terjadi karena individu kurang memahami mengenai pengetahuan keuangan dan kebiasaan pengaturan keuangan yang baik. Maka setiap individu dihadapkan pada berbagai pilihan, dalam mengambil keputusan. Salah satu keputusan yang di ambil merupakan keputusan keuangan. Dalam keputusan keuangan perlunya pengetahuan finansial literasi yang baik, guna menciptakan keselarasan antara pemasukan yang di peroleh dengan pengeluaran atau konsumsi yang di keluarkan. Karena tidak semua individu mempunyai pendapatan dan pengeluaran yang sama dalam hidupnya. Seperti yang dikatakan Widayati (2012) bahwa kecerdasan finansial merupakan salah satu aspek penting dalam kehidupan saat ini sebab kecerdasan finansial adalah kecerdasan dalam mengelola asset pribadi. Menurut Warsono (2010) pengetahuan dan implementasi seseorang atau masyarakat dalam mengelola keuangan pribadinya ini sering dikenal sebagai literasi (kemelekan) keuangan (financial literacy). Dengan adanya pengetahuan akan literasi keuangan yang baik maka akan mudah untuk mempertimbangkan suatu keputusan khususnya pada bidang keuangan atau finansial. OJK (Otoritas Jasa Keuangan) mendefinisikan literasi keuangan sebagai pengetahuan, keterampilan, dan keyakinan yang memengaruhi sikap dan perilaku untuk meningkatkan kualitas pengambilan keputusan dan pengelolaan keuangan dalam rangka mencapai kesejahteraan. Berikut ini adalah hasil survei yang dilakukan oleh Otoritas Jasa Keuangan pada tahun 2016.

Gambar 1. Grafik Perkembangan Literasi dan Inklusi Keuangan Indonesia

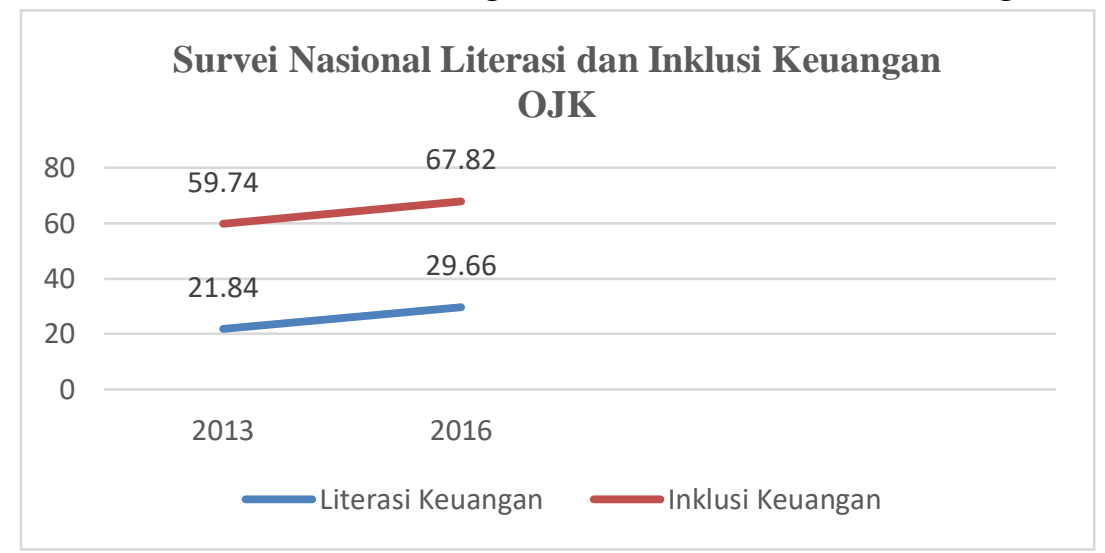

Sumber: Hasil survey OJK, 2016

Berdasarkan Gambar 1 dapat dilihat bahwa terdapat peningkatan literasi keuangan dan inklusi keuangan di Indonesia dari tahun 2013 dan 2016. Dimana indeks literasi keuangan mengalami peningkatan sebesar 7,82 \% dari tahun 2013 ke 2016. Dan untuk untuk indeks inklusi keuangan meningkat sebesar 8,08\%. Namun, menurut Jannah (2014) dalam Arvika Shinta Giffari (2018) tingkat literasi keuangan di Indonesia sendiri atau financial knowledge dari masyarakat Indonesia dapat dikatakan masih jauh tertinggal dari Malaysia, Singapura, Filipina, dan Thailand.

Sebagai generasi penerus bangsa mahasiswa dianggap sangat penting pengaruhnya dalam hal meningkatkan literasi keuangan terutama dalam pengambilan keputusan keuanganya. Karena mahasiswa dipandang mampu untuk berpikir secara kritis serta dapat mengoptimalkan peran dan fungsi mahasiswa sebagai agen of change dan social control. 
Selain itu juga mahasiswa dianggap memiliki pengetahuan yang lebih dan perilaku keuangan yang baik dibandingkan dengan orang-orang diluar sana yang seusianya tidak mengenyam pendidikan di bangku perkuliahan, walaupun tidak sedikit yang mendapat ilmu pengetahuan tidak dengan melalui pendidikan formal.

Fakultas Ekonomi dan Bisnis memiliki tiga jurusan dimana ada jurusan Ekonomi Pembangunan, Manajemen dan Akuntansi. Berikut ini adalah jumlah mahasiswa Fakultas Ekonomi dan Bisnis Universitas Palangka Raya:

Tabel 1. Jumlah Mahasiswa Fakultas Ekonomi Dan Bisnis Universitas Palangka Raya Berdasarkan Tahun Angkatan 2015 - 2018 Yang Aktif

Tahun Akademik 2018/2019

\begin{tabular}{llccccc}
\hline \multirow{2}{*}{ No } & Jurusan & \multicolumn{4}{c}{ Tahun Angkatan } & Jumlah \\
\cline { 3 - 5 } & & $\mathbf{2 0 1 5}$ & $\mathbf{2 0 1 6}$ & $\mathbf{2 0 1 7}$ & $\mathbf{2 0 1 8}$ & \\
\hline $\mathbf{1}$ & onomi Pembangunan & 90 & 132 & 145 & 136 & 503 \\
\hline $\mathbf{2}$ & inajemen & 210 & 242 & 268 & 243 & 963 \\
\hline $\mathbf{3}$ & untansi & 304 & 292 & 323 & 213 & 1.132 \\
\hline & $\quad$ Jumlah & 604 & 666 & 736 & 592 & 2.598
\end{tabular}

Sumber: Subag Akademik FEB, 2019

Mahasiswa Fakultas Ekonomi dan Bisnis Universitas Palangka Raya telah dibekali dengan ilmu-ilmu yang berhubungan dengan pengelolaan keuangan. Seperti pengajaran tentang teori portofolio dan investasi di dalam jurusan manajemen dimana mahasiswa diajarkan tentang bagaimana cara berinvestasi dengan baik sehingga dapat menghasilkan keuntungan dan pembelajaran tentang manajemen keuangan. Tetapi dari hasil survei yang dilakukan oleh Nababan dan Sadalia (2012) dalam Margaretha dan Pambudhi (2015) menyatakan bahwa literasi keuangan mahasiswa berada kalam kategori rendah, dimana masih sedikit mahasiswa yang mampu membuat perencanaan dan pengelolaan keuangan dengan baik untuk masa tuanya. Zaman yang serba digital seperti sekarang ini atau sering disebut sebagai generasi millennial, mahasiswa dinilai cenderung cuek pada keadaan sosial, lebih mengejar kebanggaan akan merk tertentu atau mengikuti perkembangan zaman yang membuat mahasiswa lebih cenderung konsumtif dan mahasiswa kebanyakan lebih mementingkan eksis di media sosial yang penting followernya banyak, sekolah atau kuliah cuma jadi ajang pamer harta orang tua untuk mereka yang orang tuanya memiliki ekonomi menengah ke atas.

Namun, ada beberapa tipe kepribadian mengelola keuangan menurut Siti Hadijah (2017) yaitu: 1) Tipe planner (perencana), dimana tipe ini memiliki kecermatan dalam membuat perencanaan dan dianggap sangat pas dalam menjadi pengelola investasi jangka panjang, 2) Tipe players (pemain), dimana tipe ini tergolong boros dalam hal keuangan, karena suka menghabiskan uang untuk bersenang-senang, 3) Tipe protector (pelindung), dimana tipe tergolong berhati-hati dan benar-benar dalam hal keuangan, masalah masa depan sudah dipersiapkan dengan matang, 4) Tipe pleaser (penggembira), tipe ini tergolong orang yang royal dalam menggunakan uang dan suka mentraktir teman-temannya atau sering 
dikenal dengan istilah sosialita. Kalimat inilah yang mendorong teori perilaku keuangan (behavioral finance theory) yang merupakan aplikasi ilmu pisikologi dalam disiplin ilmu keuangan. Perilaku keuangan sangat berperan dalam pengambilan keputusan keuangan. Seperti dalam hal pengambilan keputusan investasi tidak selalu berperilaku dengan cara yang konsisten dengan asumsi yang dibuat sesuai dengan persepsi dan pemahaman atas informasi yang diterima (Christanti dan Mahastanti, 2011). Nofsinger (2001) dalam Baiq Fitriarianti (2018) memelajari bagaimana faktor psikologis yaitu emosional dapat memengaruhi keputusan keuangan, dan pasar keuangan yaitu ilmu yang mempelajari bagaimana manusia secara aktual berperilaku dalam keputusan terkait keuangan. Perilaku keuangan (behavior finance) tersebut merupakan pendekatan yang menjelaskan bagaimana manusia melakukan investasi atau kegiatan yang berhubungan dengan keuangan yang dipengaruhi oleh faktor psikologi.

Al-Tamimi (2009) dalam Dwi Irjayanti (2017) mengungkapkan bahwa literasi keuangan memiliki pengaruh terhadap keputusan investor individu United Arab Emirates, investor yang mempunyai literasi tinggi akan cenderung menggunakan publikasi keuangan dalam mengambil suatu keputusan, sedangkan investor yang berliterasi rendah cenderung lebih mengandalkan saran dari rekan, keluarga dan lain-lain. Byrne (2007) juga menemukan bahwa pengetahuan keuangan yang rendah akan menyebabkan pembuatan rencana keuangan yang salah, dan menyebabkan bias dalam pencapaian kesejahteraan di saat usia tidak produktif lagi. Dea Rachmalita Sari (2017) dalam penelitiannya menyatakan bahwa literasi keuangan memiliki pengaruh yang positif dan signifikan terhadap pengambilan keputusan investasi. Dalam hal ini literasi keuangan sangat berpengaruh terhadap keputusan keuangan seseorang.

H1: Literasi keuangan berpengaruh positif signifikan terhadap keputusan keuangan

Sebuah studi di Rwanda oleh Sayinzoga, Bulte dan Lensik (2015) dalam Suresh, dkk (2015) mengungkapkan bahwa dengan memberikan pelatihan literasi keuangan memengaruhi perilaku keuangan. Ini membantu mengubah perilaku tabungan, pinjaman, dan pembayaran mereka. Lebih lanjut studi ini juga mengungkapkan bahwa literasi keuangan sebagai faktor penting yang menjelaskan perubahan perilaku. Di sisi lain, penelitian yang dilakukan oleh Mandell dan Klein (2009) mengenai dampak pendidikan literasi keuangan pada perilaku keuangan selanjutnya dengan membandingkan siswa yang mengambil kursus manajemen keuangan pribadi dari 79 sekolah menengah dan yang tidak mengungkapkan bahwa mereka yang memiliki yang diambil tidak lebih dari literatur finansial dari pada yang belum. Mailani Hamdani (2018) dalam penelitiannya terhadap mahasiswa Prodi Manajemen Universitas Terbuka menunjukan bahwa literasi keuangan berpengaruh sebesar 59,88\% terhadap perilaku keuangan dan 40,12\% dipengaruhi oleh variabel lain yang tidak termasuk dalam penelitiannya. Mega Rani Siahaan (2013) dalam penelitiannya terhadap mahasiswa perguruan tinggi di Surabaya menunjukkan bahwa terdapat pengaruh literasi keuangan terhadap perilaku pengelolaan keuangan. Suresh Kumar, dkk (2015) dalam penelitiannya menyatakan terdapat pengaruh yang signifikan antara literasi keuangan terhadap perilaku keuangan.

H2: Literasi keuangan berpengaruh positif signifikan terhadap perilaku keuangan

Menurut Xiao (2008) Perilaku keuangan mengacu pada perilaku manusia yang 
relevan denga pengelolaan keuangan. Ricciard V. and Simon H (2000) dalam Mdwir Siahaan (2013) menyatakan bahwa perilaku keuangan adalah keterlibatan perilaku yang ada pada diri seseorang yang meliputi emosi, sifat, kesukaan, dan berbagai macam hal yang melekat dalam diri manusia sebagai makhluk intelektual dan sosial yang berinteraksi dan melandasi munculnya keputusan melakukan suatu tindakan. Baiq Fitriarianti (2018) menyatakan bahwa perilaku keuangan berpengaruh signifikan terhadap keputusan investor. Diperkuat dengan penelitian yang dilakukan oleh Suresh Kumar, dkk (2015) yang menyatakan bahwa perilaku keuangan berpengaruh signifikan terhadap keputusan keuangan.

H3: Perilaku keuangan berpengaruh positif signifikan terhadap keputusan keuangan

Otoritas Jasa Keuangan (2014) manyatakan bahwa literasi keuangan diartikan sebagai pengetahuan, keterampilan dan keyakinan yang mempengaruhi sikap dan perilaku untuk meningkatkan kualitas pengambilan keputusan dan pengelolaan keuangan dalam rangka mencapai kesejahteraan. Assad (2012) pada penelitiannya mengungkapkan bahwa pengetahuan keuangan dan pengetahuan keuangan yang dirasakan mempengaruhi keputusan keuangan. Perilaku finansial yang dipelajari mahasiswa selama tahun-tahun ini cenderung memengaruhi keputusan yang mereka buat di masa depan (Shim, Xiao, Barber, \& Lyons, dikutip dalam Selcuk, 2015). Dalam Penelitian telah menunjukkan bahwa perilaku keuangan positif terkait dengan peningkatan kesejahteraan keuangan, penurunan tekanan keuangan dan harga diri yang lebih tinggi (Lange et al., Dikutip dalam Selcuk, 2015). Mengenai konsekuensi jangka panjang dari perilaku keuangan ini, penting untuk menyelidiki faktorfaktor mana yang memiliki dampak signifikan pada mereka dalam rangka meningkatkan kualitas hidup siswa secara umum di tahun-tahun berikutnya (Talang \& Copur, 2011; Xiao, Tang, \& Shim, 2008). Perilaku finansial memang mempengaruhi kesejahteraan finansial sehingga perlu ditekankan poin penting yaitu pengambilan keputusan finansial (McAuley, 2009). Beberapa mahasiswa masih tidak dapat menangani diri mereka sendiri dengan baik dalam membelanjakan penghasilan mereka. Bahkan banyak mahasiswa telah memutuskan untuk memiliki kartu kredit sendiri (Mandel dan Klein, 2009). Pilihan untuk menggunakan uang tunai, kredit, atau memiliki tabungan tergantung pada perilaku seseorang. Suresh Kumar, dkk (2015) dalam penelitian menyatakan bahwa adanya hubungan yang signifikan antara literasi keuangan dengan perilaku keuangan dan perilaku keuangan dengan keputusan keuangan.

H4: Literasi keuangan bepengaruh positif signifikan terhadap keputusan keuangan melalui mediasi perilaku keuangan 


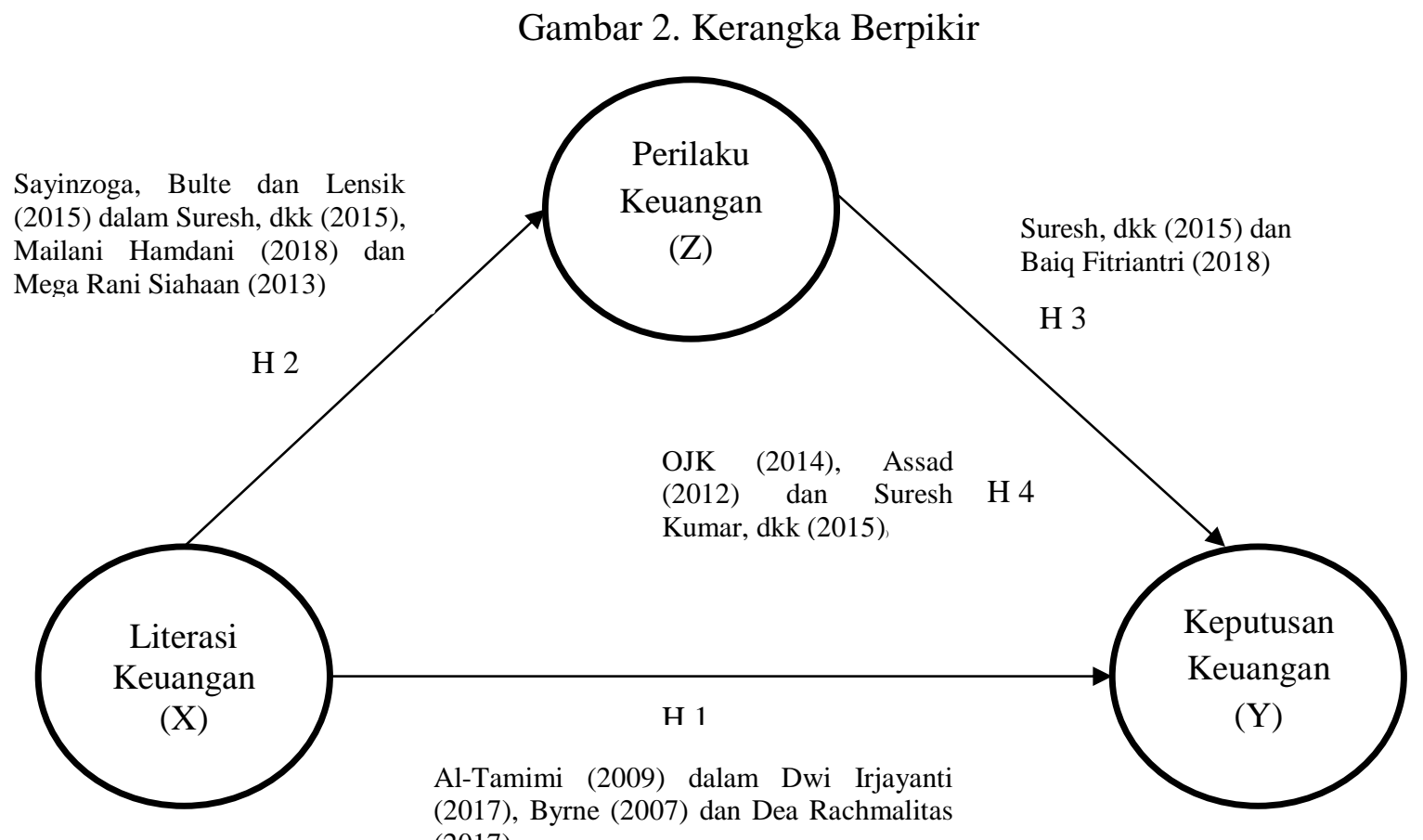

\section{Metode Penelitian}

Penelitian ini merupakan penelitian deskriptif-kuantitatif. Sumber data diperoleh dari penyebaran kusioner dan wawancara. Sampel dalam penelitian ini berjumlah 96 mahasiswa Fakultas Ekonomi dan Bisnis Universitas Palangka Raya yang dipilih dengan purposive sampling dengan menggunakan Skala Likert.

Variabel dan indikator yang digunakan dalam penelitian ini dapat dilihat dalam tabel berikut ini:

Tabel 2. Identifikasi Variabel

\begin{tabular}{|c|c|c|c|}
\hline \multicolumn{2}{|c|}{ Variabel } & Definisi & Indikator \\
\hline $\begin{array}{l}\text { Literasi } \\
(\mathrm{X})\end{array}$ & Keuangan & $\begin{array}{l}\text { Suatu proses yang mengukur beberapa baik } \\
\text { kemampuan individu dalam memahami konsep } \\
\text { keuangan dan menerapkan konsep tersebut } \\
\text { sehingga dapat terwujud pengelolaan keuangan } \\
\text { yang lebih baik. }\end{array}$ & $\begin{array}{l}\text { 1. Pengetahuan umum } \\
\text { keuangan } \\
\text { 2. Penganggaran } \\
\text { 3. Tabungan } \\
\text { 4. Investasi }\end{array}$ \\
\hline $\begin{array}{l}\text { Perilaku } \\
(\mathbf{Z})\end{array}$ & Keuangan & $\begin{array}{l}\text { Ricciard V. and Simon H (2000) dalam Mdwir } \\
\text { Siahaan (2013) menya-takan bahwa perilaku } \\
\text { keuangan adalah keterlibatan perilaku yang ada } \\
\text { pada diri seseorang yang meliputi emosi, sifat, } \\
\text { kesukaan, dan berbagai macam hal yang melekat } \\
\text { dalam diri manusia sebagai makhluk intelektual } \\
\text { dan social yang berinteraksi dan melandasi } \\
\text { munculnya keputusan melakukan suatu tin-dakan. }\end{array}$ & $\begin{array}{l}\text { 1. membayar tagihan tepat } \\
\text { waktu } \\
\text { 2. membuat anggaran } \\
\text { pengeluaran dan belanja } \\
\text { 3. mencatatat pengeluaran } \\
\text { dan belanja } \\
\text { 4. menyediakan dana untuk } \\
\text { pengeluaran tidak terduga } \\
\text { 5. menabung. }\end{array}$ \\
\hline
\end{tabular}




\begin{tabular}{lll}
\hline Keputusan & Keputusan keuangan adalah elemen & 1. Investasi \\
Keuangan (Y) & fundamental dari kehidupan jangka pendek, & 2. Pendanaan \\
& mulai dari keputusan kecil seperti & 3. Dividen \\
& memutuskan apakah keputusan besar atau & \\
& tidak. Ini juga dapat didefinisikan sebagai \\
& pertimbangan atau pilihan dari kemungkinan \\
& pilihan yang dibuat baik itu dalam \\
& berinvestasi.
\end{tabular}

Sumber: Data sekunder dikembangkan, 2019

Data dianalisis dengan menggunakan metode Partial Least Square (PLS) dan menggunakan tools SmartPLS. PLS adalah salah satu metode alternatif SEM (structural equation modeling) yang digunakan untuk mengatasi permasalahan dalam hubungan. Jumlah sampel tidak harus banyak dan tidak memerlukan banyak asumsi.

\section{Hasil dan Pembahasan}

Setelah pengumpulan data dengan mengunakan kuesioner yang disebarkan kepada responden yakni Mahasiswa Fakultas Ekonomi dan Bisnis Universitas Palangka Raya yang berjumlah 96 orang. Informasi tentang karakteristik responden dapat dilihat pada Tabel 3. berikut ini.

Tabel 3. Karakteristik Responden

\begin{tabular}{lcc}
\hline \multicolumn{1}{c}{ Uraian } & Frekuensi & Persentase \% \\
\hline Jurusan: & & \\
Ekonomi Pembangunan & 19 & $20 \%$ \\
Manajemen & 36 & $37 \%$ \\
Akuntansi & 41 & $43 \%$ \\
\hline Total & $\mathbf{9 6}$ & $\mathbf{1 0 0 \%}$ \\
\hline Angkatan: & & \\
$\mathbf{2 0 1 5}$ & 22 & $23 \%$ \\
$\mathbf{2 0 1 6}$ & 24 & $25 \%$ \\
$\mathbf{2 0 1 7}$ & 28 & $29 \%$ \\
$\mathbf{2 0 1 8}$ & 22 & $23 \%$ \\
\hline Total & $\mathbf{9 6}$ & $\mathbf{1 0 0 \%}$ \\
\hline Jenis Kelamin: & & \\
Laki-laki & 45 & $47 \%$ \\
$\quad$ Perempuan & 51 & $52 \%$ \\
\hline Total & $\mathbf{9 6}$ & $\mathbf{1 0 0 \%}$ \\
\hline
\end{tabular}

Sumber: Data primer diolah, 2019

Berdasarkan Tabel 4.1 dapat dilihat bahwa responden pada Fakultas Ekonomi dan Bisnis Universitas Palangka Raya dilihat dari jurusan untuk Mahasiswa Ekonomi Pembangunan sebanyak 19 orang atau 20\%, Manajemen sebanyak 36 orang atau 37\%, dan Akuntansi sebanyak 41 orang atau $43 \%$ dari jumlah keseluruhan responden. Dilihat dari 
tahun angkatan pada penelitian ini didominasi oleh Mahasiswa angkatan 2017 berjumlah 28 orang atau 29\%, ini disebabkan karena jumlah Mahasiswa pada angkatan 2017 secara keseluruhan memang besar dari pada angkatan lain di Fakultas Ekonomi dan Bisnis Universitas Palangka Raya, dan untuk Mahasiswa angkatan 2016 berjumlah 24 orang atau 25\%, Mahasiswa angkatan 2015 berjumlah 22 orang atau 23\% dan Mahasiswa angkatan 2018 berjumlah 22 orang atau 23\% dari jumlah responden. Dilihat dari jenis kelamin responden pada penelitian ini didominasi oleh perempuan yang berjumlah 51 orang atau $53 \%$ lebih banyak dari jumlah laki-laki yang hanya berjumlah 45 orang atau $47 \%$.

\section{Evaluasi Measurement model (Outer model)}

Adapun model pengukuran untuk uji validitas dan reliabilitas, koefisien determinasi model dan koefisien jalur, dapat dilihat pada Gambar 3. berikut:

Gambar 3. Tampilan Hasil PLS Algorith

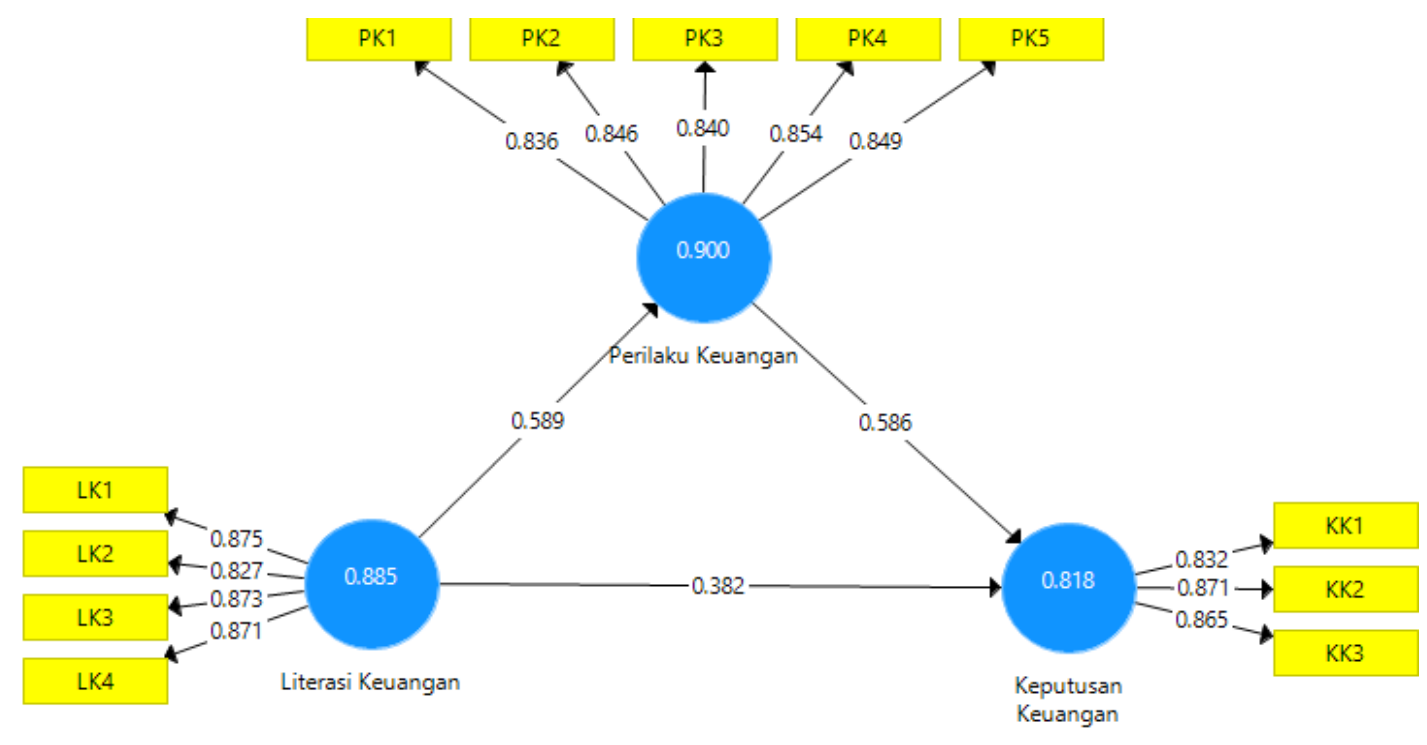

Sumber: Hasil Perhitungan Akhir Algorithm PLS

Sedangkan untuk rangkuman hasil uji validitas dan hasil uji reliabilitas dapat dilihat pada Tabel 4. dan Tabel 5. sebagai berikut: 
Tabel 4. Hasil Uji Validitas

\begin{tabular}{|c|c|c|c|c|}
\hline \multirow{2}{*}{$\begin{array}{c}\text { Measurment } \\
\text { Model }\end{array}$} & \multicolumn{2}{|r|}{ Hasil } & \multirow[t]{2}{*}{ Nilai Kritis } & \multirow{2}{*}{$\begin{array}{c}\text { Evaluasi } \\
\text { Model }\end{array}$} \\
\hline & \multicolumn{2}{|r|}{ Outer Model } & & \\
\hline \multirow{4}{*}{$\begin{array}{l}\text { Discriminant } \\
\text { Validity }\end{array}$} & Variabel & $A V E$ & \multirow{4}{*}{$>0,5$} & \\
\hline & LK & 0,743 & & Valid \\
\hline & KK & 0,733 & & Valid \\
\hline & PK & 0,714 & & Valid \\
\hline \multirow{13}{*}{$\begin{array}{l}\text { Convergen } \\
\text { Validity }\end{array}$} & Indikator & Outer Loading & & \\
\hline & LK. 1 & 0,875 & \multirow{9}{*}{$>0,5$} & Valid \\
\hline & LK. 2 & 0,827 & & Valid \\
\hline & LK. 3 & 0,873 & & Valid \\
\hline & LK. 4 & 0,871 & & Valid \\
\hline & KK.1 & 0,832 & & Valid \\
\hline & KK. 2 & 0,871 & & Valid \\
\hline & KK. 3 & 0,865 & & Valid \\
\hline & PK. 1 & 0,836 & & Valid \\
\hline & PK. 2 & 0,846 & & Valid \\
\hline & PK. 3 & 0,840 & \multirow{3}{*}{$>0,5$} & Valid \\
\hline & PK. 4 & 0,854 & & Valid \\
\hline & PK. 5 & 0,849 & & Valid \\
\hline
\end{tabular}

Sumber: Hasil Olahan SmartPLS 3.0

Berdasarkan Tabel 4. nilai $A V E$ variabel literasi keuangan, perilaku keuangan dan keputusan keuangan di atas 0,5 . Dengan demikian dapat dinyatakan bahwa setiap variabel telah memiliki discriminant validity yang baik.

Sedangkan untuk convergen validity berdasarkan Tabel 4. diketahui bahwa masing-masing indikator variabel penelitian memiliki nilai outer loading diatas 0,5. Sehingga semua indikator dinyatakan valid atau layak untuk digunakan untuk penelitian dan analisis lebih lanjut.

Tabel 5. Hasil Uji Reliabilitas

\begin{tabular}{|c|c|c|c|c|c|}
\hline Variabel & $\begin{array}{l}\text { Composite } \\
\text { Reliability }\end{array}$ & $\begin{array}{l}\text { Nilai } \\
\text { Kritis }\end{array}$ & $\begin{array}{c}\text { Cronbachs } \\
\text { Alpha }\end{array}$ & $\begin{array}{l}\text { Nilai } \\
\text { Kritis }\end{array}$ & $\begin{array}{c}\text { Evaluasi } \\
\text { Model }\end{array}$ \\
\hline LK & 0,920 & \multirow{3}{*}{$>0,7$} & 0,885 & \multirow{3}{*}{$>0,6$} & \multirow{3}{*}{ Reliabel } \\
\hline KK & 0,892 & & 0,818 & & \\
\hline PK & 0,926 & & 0,900 & & \\
\hline
\end{tabular}

Sumber: Hasil Olahan SmartPLS 3.0

Konstruk dinyatakan reliabel jika memiliki nilai composite reliability di atas 0,7 dan cronbach's alpha di atas 0,6. Berdasarkan Tabel 5, semua konstruk memiliki nilai composite reliability di atas 0,7 dan cronbach's alpha di atas 0,6. Jadi dapat disimpulkan bahwa konstruk memiliki reliabilitas yang baik. 


\section{Pengujian Inner Model (Model Struktural)}

Pengujian inner model dilakukan untuk melihat nilai signifikasi hubungan antara variabel laten dengan uji t sesuai parameter jalur strukturalnya dan nilai $\mathrm{R}$-square dari model penelitian. Pengujian tersebut dilakukan melalui SmartPLS 3.0 dengan melakukan langkah calculate-boostrapping dan diperoleh hasil sebagai berikut:

Tabel 6. Path Coefficient (Mean, STDEV, T-Value, P-Values)

\begin{tabular}{cccccc}
\hline & $\begin{array}{c}\text { Original } \\
\text { sample } \\
\text { estimate }\end{array}$ & $\begin{array}{c}\text { Mean of } \\
\text { subsamples }\end{array}$ & $\begin{array}{c}\text { Standard } \\
\text { deviation }\end{array}$ & $\begin{array}{c}\text { T- } \\
\text { Statistic }\end{array}$ & $\begin{array}{c}\text { P- } \\
\text { Values }\end{array}$ \\
\hline LK -> KK & 0,382 & 0,380 & 0,078 & 4,881 & 0,000 \\
\hline LK -> PK & 0,589 & 0,588 & 0,074 & 7,976 & 0,000 \\
\hline PK-> KK & 0,586 & 0,590 & 0.075 & 7,813 & 0,000 \\
\hline
\end{tabular}

Sumber: Hasil Olahan SmartPLS 3.0

Tabel 7. Specific Indirect Effects (Mean, STDEV, T-Value, P-Values)

\begin{tabular}{cccccc}
\hline & $\begin{array}{c}\text { Original } \\
\text { sample } \\
\text { estimate }\end{array}$ & $\begin{array}{c}\text { Mean of } \\
\text { subsamples }\end{array}$ & $\begin{array}{c}\text { Standard } \\
\text { deviation }\end{array}$ & $\begin{array}{c}\text { T- } \\
\text { Statistic }\end{array}$ & $\begin{array}{c}\text { P- } \\
\text { Values }\end{array}$ \\
\hline LK -> PK -> KK & 0,345 & 0,346 & 0,061 & 5,623 & 0,000 \\
\hline
\end{tabular}

Sumber: Hasil Olahan SmartPLS 3.0

Tabel 8. Total Effects (Mean, STDEV, T-Value, P-Values)

\begin{tabular}{cccccc}
\hline & $\begin{array}{c}\text { Original } \\
\text { sample } \\
\text { estimate }\end{array}$ & $\begin{array}{c}\text { Mean of } \\
\text { subsamples }\end{array}$ & $\begin{array}{c}\text { Standard } \\
\text { deviation }\end{array}$ & $\begin{array}{c}\text { T- } \\
\text { Statistic }\end{array}$ & $\begin{array}{c}\text { P- } \\
\text { Values }\end{array}$ \\
\hline LK -> KK & 0,727 & 0,726 & 0,052 & 14,073 & 0,000 \\
\hline LK -> PK & 0,589 & 0,588 & 0,074 & 7,976 & 0,000 \\
\hline PK -> KK & 0,586 & 0,590 & 0,075 & 7,813 & 0,000 \\
\hline
\end{tabular}

Sumber: Hasil Olahan SmartPLS 3.0

Hasil pengujian pada Tabel 6, Tabel 7, dan Tabel 8 digunakan untuk menguji hipotesis yang ada. Pengujian pertama untuk melihat literasi keuangan berpengaruh positif signifikan terhadap keputusan keuangan. Hasil pengujian menunjukkan bahwa nilai original sample estimate LK -> KK adalah sebesar 0,382 dengan signifikansi 5\% yang di tunjukkan dengan nilai t-statistik 4,881 lebih besar dari nilai t-tabel sebesar 1,962 serta p-values 0,000 lebih kecil dari 0,05. Sedangkan nilai original sample estimate positif mengindentifikasikan bahwa literasi keuangan berpengaruh positif terhadap keputusan keuangan. Kemudian pada pengaruh langsung literasi keuangan terhadap keputusan keuangan dengan koefisien jalur 0,382 sedangkan untuk pengaruh tidak langsung sebesar 0,345 . Untuk melihat pengaruh totalnya pengaruh langsung ditambah dengan pengaruh tidak langsung $(0,382+0,345=$ 0,727). Hasil ini memperkuat bahwa pengaruh literasi keuangan terhadap keputusan keuangan positif (variabel eksogen dapat mempengaruhi variabel endogen secara langsung. Konsisten dengan pendapat Al-Tamimi (2009) dalam Dwi Irjayanti (2017), Byrne (2007), 
diperkuat lagi dari hasil penelitian yang dilakukan oleh Dea Rachmalitas (2015) yang menyatakan bahwa literasi keuangan berpengaruh positif dan signifikan terhadap keputusan keuangan.

Pengujian kedua dilakukan untuk melihat apakah literasi keuangan berpengaruh positif signifikan terhadap perilaku keuangan. Hasil pengujian dapat dilihat dari Tabel 6, LK $>$ PK memperoleh nilai original sample estimate sebesar 0,589 dengan nilai t-statistik 7,976 $>1,962$ serta $\mathrm{p}$-values $0,000<0,05$ yang berarti literasi keuangan berpengaruh positif dan signifikan terhadap perilaku keuangan dengan tingkat signifikansi 5\%. Konsisten dengan pendapat Sayinzoga, Bulte, dan Lensik (2015) dalam Suresh Kumar, dkk (2015) dan konsisten dengan hasil penelitian yang dilakukan oleh Mailani Hamdani (2018), Mega Rani Siahaan (2013) dan Suresh Kumar, dkk (2015) yang menyatakan bahwa literasi keuangan berpengaruh signifikan terhadap perilaku keuangan.

Pengujian ketiga dilakukan untuk melihat apakah perilaku keuangan berpengaruh positif signifikan terhadap keputusan keuangan. Hasil pengujian dapat dilihat dari Tabel 6, PK -> KK memperoleh nilai original sample estimate sebesar 0,586 dengan nilai t-statistik $7,813>1,962$ serta p-values $0,000<0,05$ yang berarti perilaku keuangan berpengaruh positif dan signifikan keputusan keuangan dengan tingkat signifikansi 5\%. Konsisten dengan hasil penelitian yang dilakukan oleh Suresh Kumar, dkk (2015) dan Baiq Fitriantri (2018) yang menyatakan bahwa perilaku keuangan berpengaruh signifikan terhadap keputusan keuangan.

Pengujian keempat ditunjukan untuk melihat secara simultan pengaruh literasi keuangan terhadap keputusan keuangan melalui perilaku keuangan sebagai variabel mediasi (intervening). Hasil pengujian dapat dilihat pada Tabel 7. Specific Indirect Effects dari LK$>$ PK $->$ KK, nilai original sample estimate sebesar 0,345 dan nilai t-statistik sebesar 5,623 di atas nilai t-tabel 1,962 p-values $0,000<0,05$ yang berarti literasi keuangan berpengaruh positif signifikan terhadap keputusan melalui perilaku keuangan, dengan pengaruh mediasi sebagian (partial mediation). Konsisten dengan pernyataan Otoritas Jasa Keuangan (2014) yang menyatakan bahwa literasi keuangan diartikan sebagai pengetahuan, keterampilan dan keyakinan yang memengaruhi sikap dan perilaku untuk meningkatkan kualitas pengambilan keputusan dan pengelolaan keuangan dalam rangka mencapai kesejahteraan. Diperkuat lagi dalam penelitian Suresh Kumar, dkk (2015) yang menyatakan bahwa literasi keuangan berpengaruh signifikan terhadap perilaku keuangan dan perilaku keuangan juga

berpengaruh signifikan terhadap keputusan keuangan, yang artinya bahwa literasi keuangan berpengaruh terhadap perilaku keuangan dan kemudian diterapkan terhadap keputusan keuangan.

\section{R-square}

Pengujian terhadap inner model dilakukan dengan melihat nilai R-square. Hasil R-square terangkum dalam Tabel 9 berikut ini:

Tabel 9. R- Square

\begin{tabular}{cc}
\hline Variabel & Nilai R-Square \\
\hline Perilaku Keuangan & 0,347 \\
\hline Keputusan Keuangan & 0.753
\end{tabular}

Sumber: Hasil Olahan SmartPLS 3.0

Berdasarkan sajian data pada Tabel 9. dapat diketahui nilai R-square untuk perilaku 
keuangan 0,347 yang berarti variabel literasi keuangan mempengaruhi variabel perilaku keuangan masuk dalam kategori moderat (sedang).

Sedangkan untuk variabel keputusan keuangan nilai R-square sebesar 0,753 yang artinya variabel literasi keuangan mempengaruhi variabel keputusan keuangan melalui variabel perilaku keuangan masuk dalam kategori kuat atau baik. Berdasarkan nilai R-square tersebut dapat dikatakan keputusan keuangan dipengaruhi oleh variabel independen dan variabel mediasi (intervening) sebesar 75\%, sedangkan sisanya 25\% dipengaruhi oleh variabel lain.

Selanjutnya untuk menghitung nilai Q Square dapat dilakukan sebagai berikut.

Diketahui: $\quad R_{1}^{2}=0,347$

$$
Q^{2}=1-\left(1-R_{1}^{2}\right)\left(1-R_{2}^{2}\right) \ldots\left(1-R_{p}^{2}\right)
$$

Sehingga:

$$
R_{2}^{2}=0,753
$$

$Q^{2}=1-\left(1-R_{1}^{2}\right)\left(1-R_{2}^{2}\right)$

$Q^{2}=1-(1-0,347)(1-0,753)$

$Q^{2}=1-(0,653)(0,247)$

$Q^{2}=1-(0,161)$

$Q^{2}=0,839$

Apabila $Q$-squre lebih dari 0 (nol), maka model layak dikatakan memiliki nilai prediktif yang relevan. Besarnya $Q^{2}$ memiliki nilai dengan rentang $0<Q^{2}<1$, dimana semakin mendekati 1 berarti model semakin baik. Berdasarkan perhitungan di atas nilai Prediction Relevance (Q Square) adalah 0,839 yang artinya memiliki kapasitas prediksi yang besar dan model yang baik.

\section{SIMPULAN}

Penelitian ini memberikan bukti empiris mengenai literasi keuangan terhadap keputusan keuangan melalui perilaku keuangan. Penelitian ini dilakukan di Fakultas Ekonomi dan Bisnis Universitas Palangka Raya. Hasil penelitian menunjukkan bahwa:

Literasi keuangan berpengaruh positif signifikan terhadap keputusan keuangan mahasiswa Fakultas Ekonomi dan Bisnis Universitas Palangka Raya. Literasi keuangan berpengaruh positif signifikan terhadap perilaku keuangan mahasiswa Fakultas Ekonomi dan Bisnis Universitas Palangka Raya. Perilaku keuangan berpengaruh positif signifikan terhadap keputusan keuangan mahasiswa Fakultas Ekonomi dan Bisnis Universitas Palangka Raya. Literasi keuangan berpengaruh positif signifikan terhadap keputusan keuangan melalui perilaku keuangan sebagai mediasi mahasiswa Fakultas Ekonomi dan Bisnis Universitas Palangka Raya.

Saran yang dapat diberikan berdasarkan hasil penelitian adalah: Penelitian selanjutnya diharapkan agar mendapatkan suatu model penelitian yang baik dengan didukung oleh teori yang kuat dan disarankan untuk lebih memperbanyak referensi penelitian yang mampu mendukung topik yang diteliti. Penelitian selanjutnya diharapkan dapat melakukan pengujian model yang lebih dikembangkan, sehingga hasil penelitian dapat lebih memberi gambaran yang lebih baik. Penelitian selanjutnya diharapkan agar dapat melakukan penelitian pada subjek yang lebih besar dan mahasiswa di luar dari Fakultas Ekonomi dan Bisnis Universitas Palangka Raya. 


\section{REFERENSI}

Byrne, Alistair. (2007). Employee Saving and Investment Decisions in Defined Contribution Pension Plans: SurveyEvidence from the UK.The Financial Services Review, Vol. 16 No.1

Christanti, Natalia dan Linda Ariany Mahastanti. (2011). Faktor-faktor yang Dipertimbangkan Investor dalam Melakukan Investasi. Jurnal Manajemen Teori dan Terapan, Volume 4 No. 3, Desember 2011

Fitriarianti, B. (2018). Pengaruh Literasi Keuangan, Perilaku Keuangan Dan Pendapatan Terhadap Keputusan Berinvestasi. In Proseding Seminar Nasional Akuntansi (Vol. 1, No. 1).

Giffari, A. S. (2018). Analisis Literasi Finansial Mahasiswa Fakultas Ekonomi Universitas Islam Indonesia.

Ghozali, Iman \& Latan Hengky. (2015). Partial Least Squares Konsep, Teknik dan Aplikasi menggunakan Program SamartPLS 3.0. Semarang: Undip

Hamdani, M. (2018). Analisis Tingkat Literasi Keuangan dan Pengaruhnya Terhadap Perilaku Keuangan Pada Mahasiswa Prodi Manajemen Universitas Terbuka. Jurnal Bakti Masyarakat Indonesia, 1(1).

Hussein, Ananda. S. (2015). Penelitian Bisnis dan Manajemen Menggunakan Partial Least Squares (PLS) dengan SmartPLS 3.0. Malang

Irjayanti, D. (2017). Pengaruh Literasi Keuangan, Representativeness, Familiarity, Dan Persepsi Risiko Terhadap Pengambilan Keputusan Investasi Pada Investor Surabaya Dan Sidoarjo (Doctoral dissertation, STIE PERBANAS SURABAYA).

Jaya, I Gede \& Sumertajaya, I Made. (2008). Pemodelan Persamaan Struktural Dengan Partial Least Square.Yogyakarta

Karmis. (2010). Pengantar Manajemen Keuangan. Jakarta: Kencana Prenada Media Group. Kumar, Suresh \& dkk. (2015). Pengaruh Literasi Keuangan Terhadap Perilaku Keuangan Dan Implikasinya Pada Keputusan Keuangan, hlm 170-172

Margaretha, F., \& Pambudhi, R. A. (2015). Tingkat literasi keuangan pada mahasiswa S-1 fakultas ekonomi. Jurnal Manajemen dan Kewirausahaan, 17(1), 76-85.

Palamba, Febria G S. (2018), Literasi Keuangan Berpengaruh Terhadap Perilaku Konsumtif Mahasiswa Program Studi Akuntansi Universitas Sanata Dharma.

Putri, W. W., \& Hamidi, M. (2019). Pengaruh literasi keuangan, efikasi keuangan, dan faktor demografi terhadap pengambilan keputusan investasi (studi kasus pada mahasiswa magister manajemen fakultas ekonomi universitas andalas padang). Jurnal Ilmiah Mahasiswa Ekonomi Manajemen, 4(1), 210-224.

Rasyid, Royeni. (2012). Analisis Tingkat Literasi Keuangan Mahasiswa Program Studi Manajemen Fakultas Ekonomi Universitas Negeri Padang. Jurnal Kajian Manajemen Bisnis, hlm 99-104

Sari, D. R. (2017). Pengaruh Literasi Keuangan, Pendapatan, Dan Pendidikan Terhadap Keputusan Investasi Keluarga Etnis China Di Surabaya (Doctoral dissertation, STIE PERBANAS SURABAYA).

Sari, Rita Puspita. (2018). Analisis Pengaruh Faktor Pribadi dan Faktor Psikologis Terhadap Keputusan Pembelian Laptop Merk Acer.

Siahaan, M. D. R. (2013). Pengaruh Literasi Keuangan Terhadap Perilaku Pengelolaan 
Keuangan Pada Mahasiswa Perguruan Tinggi Di Surabaya (Doctoral dissertation, STIE PERBANAS SURABAYA).

Siswandi. (2010). Manajemen Keuangan. Jakarta: Lentara Ilmu Cendekia

Soetiono, Kusumaningtuti. S \& Setiawan, Cecep. (2018). Literasi dan Inklusi Keuangan Indonesi. Jakarta: PT. Rajagrafindo Persada

Sugiyono. (2013). Metode Penelitian Manajemen. Bandung: Alfabeta.

Sugiyono. (2018). Metode Penelitian Kuantitatif. Bandung: Alfabeta.

Sugiyono. (2006). Metode Penelitian Kuantitatif, Kualitatif dan R\&D. Bandung: Alfabeta.

Sugiyono. (2010). Metode Penelitian Pendidikan Pendekatan Kuantitatif, kualitatif,dan $R \& D$. Bandung: Alfabeta.

Sukardi. (2007). Metodologi Penelitian Pendidikan Kompetensi dan Praktiknya. Jakarta: Bumi Aksara.

Suryanto. (2017). Pola Perilaku Keuangan Mahasiswa di Perguruan Tinggi. Jurnal Ilmu Politik dan Komunikasi.

Widayati, Irin. (2012). Faktor-Faktor Yang Mempengaruhi Literasi Finansial Mahasiswa Fakultas Ekonomi dan Bisnis Universitas Brawijaya, Jurnal Asset: Jurnal Akuntansi dan Pendidikan, 1 (1): 89-99

Warsono. 2010. Prinsip-Prinsip dan Praktik Keuangan Pribadi. Jurnal Bisnis dan Akuntansi, Vol. 13, No. 2, hlm. 137 - 151.

Xiao, J. J. (2008). Applying behavior theories to financial behavior. In: Handbook of consumer finance research. Springer New York, 2008. p. 69-81. 